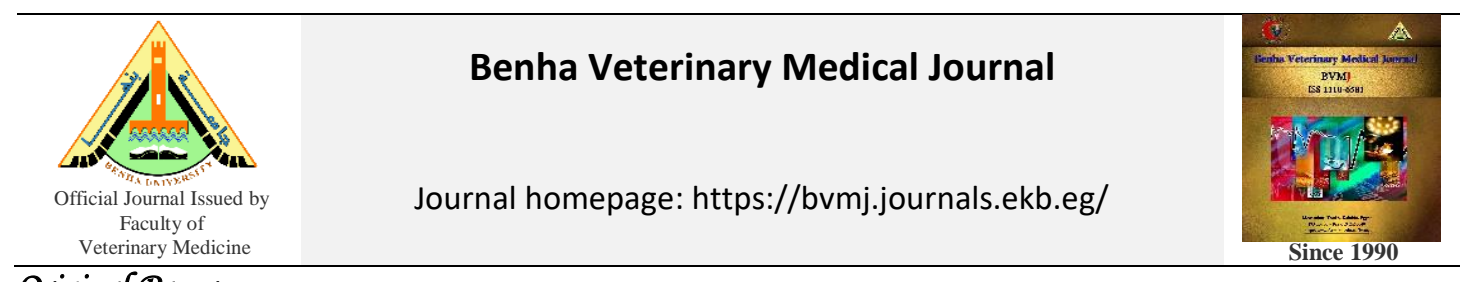

Original Paper

\title{
Assessment of pulmonary function test, acute phase proteins, cytokines and electrocardiographic changes in naturally occurring bovine respiratory disease of feedlot cattle calves
}

Mohamed A. Ramadan', Yassein M. Abd El-Raof ${ }^{1}$, Mohamed M. Zeineldin ${ }^{1}$, Hussam E. M. El-attar ${ }^{1}$, Abdelghany H. abdelghany ${ }^{2}$, Mohamed M. Ghanem ${ }^{1}$

${ }^{1}$ Animal Medicine Department, Faculty of Veterinary Medicine, Benha University, Egypt

${ }^{2}$ Animal Medicine Department, Faculty of Veterinary Medicine, Menoufiya University, Egypt

\begin{tabular}{|c|c|}
\hline ARTICLE INFO & ABSTRACT \\
\hline $\begin{array}{l}\text { Keywords } \\
\text { Acute phase proteins } \\
\text { BRD } \\
\text { Cytokines } \\
\text { ECG. } \\
\text { Pulmonary function }\end{array}$ & $\begin{array}{l}\text { The aim of this study was to evaluate pulmonary function test, acute phase proteins, pro- } \\
\text { inflammatory cytokines, electrolyte balance and electrocardiographic alterations in bovine } \\
\text { respiratory diseases (BRD) affected calves compared to pen matched healthy control calves. A } \\
\text { total of } 30 \text { calves ( } 20 \text { BRD affected calves and } 10 \text { apparently healthy calves) were used in this } \\
\text { study. BRD affected calves showed significant }(P<0.05) \text { reduction in blood pH, partial } \\
\text { pressure of oxygen, oxygen saturation, calcium, phosphorus, magnesium, sodium and chloride, } \\
\text { and significant }(P<0.05) \text { increase in partial pressure of carbon dioxide, total carbon dioxide } \\
\text { and potassium. Acute phase proteins and proinflammatory cytokines assessment revealed a } \\
\text { significant }(P<0.05) \text { increase of serum amyloid A, haptoglobin, fibrinogen and interleukin-6 } \\
\text { in diseased calves compared to healthy control calves. Electrocardiographic examination of } \\
\text { BRD affected calves revealed a significant increase in heart rate with a significant }(P<0.05) \\
\text { alteration in electrocardiographic changes (ECG) wave trace parameters (P wave, QRS } \\
\text { complex, T wave, PR interval, QT interval). In conclusion, measurement of pulmonary } \\
\text { function test, APPs, cytokines and ECG could be used as valuable and early diagnostic tools } \\
\text { for BRD diagnosis in feedlot cattle calves. }\end{array}$ \\
\hline
\end{tabular}

\section{INTRODUCTION}

Bovine respiratory disease (BRD) is one of the most economically significant diseases in cattle industry especially in intensely raised, recently weaned and newly transported calves (Loneragan et al., 2001). The biggest challenges in bovine medicine is an early detection of clinical cases of diseases, especially impertant the subclinical form, which can be easily missed and cause important economic losses (Arslan and Ozcan, 2018). It has been reported that $37-68 \%$ of calves that never received treatment for BRD during the finishing period had lung lesions at the slaughter time (Thompson et al., 2006). For this reason, early identifying of an accurate method to classify calves that are at greater risk of becoming sick is the key for optimal calves' health (Abdallah et al., 2016; Zeineldin et al., 2019).

Recently, the possibility to use acute phase proteins (APPs), cytokines, pulmonary function test and electrocardiography (ECG) as diagnostic biomarkers of infection has expanded significantly in the context of respiratory medicine. The acute inflammatory process initiates the acute phase reaction that results in increase the concentration of APPs in diseased calves (Heller and Johns, 2015). APPs have been recently proposed as sensitive and rapid indicators of inflammatory processes in ruminants (Gonzales et al., 2011). APPs play an important role in eliminating the infectious agents and activating the repair process toward the normal function (Tothova et al., 2015). Assessment of blood gases and related clinical parameters are also considered an important diagnostic indicators for BRD that help in early treatment decision (Constable et al., 2017). ECG assessment is also a useful tool in accurate diagnosis and evaluation of cardiac diseases or dysfunctions secondary to other systemic disease (Ghanem, 1997). Therefore, our hypothesis was that assessment of pulmonary function test, APPs and ECG changes in BRD affected calves with other clinical variables could be used to influence treatment decisions at the time of initial disease diagnosis. The objective of this study was to evaluate pulmonary function test, APPs, electrolyte balance and ECG alterations in BRD affected calves compared to pen matched healthy control calves.

\section{MATERIAL AND METHODS}

\subsection{Animals and samples collection}

This study was carried out in a farm in Gharbiya Governorate. A total of 30 calves (3-9 months old) were selected and used in this study. These calves were recently transported to the farm from sale barns before beginning this study. All calves were classified based on clinical examination into the following groups: clinically healthy

\footnotetext{
* Corresponding author: Prof. Mohamed M. Ghanem, Department of Animal Medicine, Faculty of Veterinary Medicine,
}

Benha University, Benha, 13511, Egypt. Tel: (+2) 01223565658, E-mail: mohamed.ghanem@fvtm.bu.edu.eg. 
calves (Control, $\mathrm{n}=10$ ), and calves suffered from bovine respiratory disease (BRD affected calves, $n=20$ ). Calves suspected to be suffering from BRD were visually examined for the presence of nasal or ocular discharge, respiratory distress, cough, depression and inappetence. When two or more of these clinical signs were observed, rectal temperature of calf was recorded. Using the clinical scoring system (McGuirk, 2008), a calf with a score of 5 or more was classified as morbid and included in the study. Calves were not included in the study if there was a presence of concurrent diseases. All calves were subjected to complete clinical examination including body temperature, pulse rate, respiratory rate and thoracic auscultation (Radostits et al., 2000).

Two blood samples were collected from each calf using jugular vein puncture. The first blood sample $(2 \mathrm{ml})$ was collected in syringe containing heparin $(50 \mathrm{IU} / \mathrm{ml})$ used for blood gases and plasma fibrinogen estimation (Fararh et al., 2017). The second blood sample was collected without anticoagulant, clotted at room temperature for $20 \mathrm{~min}$, centrifuged at $3000 \mathrm{rpm}$ for $10 \mathrm{~min}$, and the clear nonhemolyzed serum samples were separated and stored at -20 ${ }^{\circ} \mathrm{C}$ until subsequent biochemical analysis.

\subsection{Blood gas analysis}

Immediately after vein-puncture, the tip of the needle was sealed with a rubber stopper in order to prevent gas from moving in or out. The samples were placed in a bed of crushed ice, taken immediately to the laboratory for analysis no more than one hour after collection. The blood samples were analyzed for $\mathrm{pH}$, partial oxygen pressure $\left(\mathrm{PO}_{2}\right)$, partial dioxide pressure $\left(\mathrm{PCO}_{2}\right)$, bicarbonate $\left(\mathrm{HCO}_{3}\right)$ concentrations, total carbon dioxide $\left(\mathrm{tCO}_{2}\right)$ and oxygen saturation $\left(\mathrm{SO}_{2}\right)$ using blood gas analyzer (Hussein and Aamer, 2013).

\subsection{Acute phase proteins and proinflammatory cytokines measurement}

Serum haptoglobin (Hp) concentration was determined by ELISA kit according to method described by Idoate et al. (2015). Serum amyloid A (SAA) concentration was measured with a commercially available ELISA kit according to method described by Alsemgeest et al. (1994). Serum fibrinogen $(\mathrm{Fb})$ concentration was measured according to method described by Becker et al. (1984). Interleukin-6 (IL-6) level was determined from undiluted serum samples using commercially available ELISA kits according to method described by Kabu et al. (2016a).

\subsection{Serum minerals and electrolytes measurement}

Serum $\mathrm{Ca}$, inorganic $\mathrm{P}, \mathrm{Cl}, \mathrm{Na}$ and $\mathrm{K}$ levels were determined using spectrophotometer according to the method described by Chessborough (1991). Serum magnesium (Mg) levels were determined by using atomic absorption spectrophotometer by as described by Devlin (1997).

\subsection{Electrocardiographic examination}

The electrocardiogram (ECG) was recorded with base apex lead system II using limb lead. Calves were kept in standing position without any tranquilizers or sedative. When animals got calm (decreasing muscle tremors), ECGs were recorded, using alligator-type electrodes attached to the skin after cleaning it with ethanol and applying ethyl alcohol to improve the contact. Base apex lead system II was applied as; the right forelimb electrode was placed on the right side of the neck along the jugular groove one third of the way up the neck. The left forelimb electrode was placed on the ventral midline under the apex of the heart. The ground cables were placed on the left and right stifle joints. Alligator clips moisten with alcohol were used (Ghanem, 1997). ECG should reveal a distinct $\mathrm{P}$ wave (atrial depolarization), QRS complex (ventricular depolarization), and $T$ wave (ventricular repolarization). All ECGs were obtained with a single channel electrocardiographic machine (BTL-08 SD ECG, Industries Ltd.161 Cleveland Way, Steven age, SG1 $6 \mathrm{BU}, \mathrm{UK}$ ) with paper speed of $25 \mathrm{~mm} / \mathrm{s}$ and calibration of $10 \mathrm{~mm}$ equal to $1 \mathrm{mV}$. For measuring ECG parameters, the ECG was analyzed using a magnifying glass. In this method, precision of duration is $0.02 \mathrm{sec}$. and amplitude is $0.1 \mathrm{mV}$.

\subsection{Statistical analysis}

Statistical analysis was performed using IBM SPSS Statistics version 20 (IBM Armonk, NY, USA). The data was statistically analyzed using independent sample $t$-test was performed to compare control healthy with diseased animal as previously described by Bailey (2008). Values were represented as means \pm standard error. Differences were considered statistically significantly when $P<0.05$.

\section{RESULTS}

\subsection{Clinical signs}

calves suffered from BRD developed varying degree of depression, shallow rapid respiration, anorexia, loss of body weight, nasal discharge, sever dyspnea with mouth breathing, congestion of ocular mucous membrane with ocular discharge and some BRD cases suffered from painful cough.

Auscultation of the lung in BRD affected calves showed abnormal lung sounds including loud wheezing, crackling sound and moist rales. Frictional sound and exaggerated vesicular sounds were also heard.

BRD affected calves also showed significant $(\mathrm{P}<0.05)$ increase in body temperature $(40.62 \pm 0.09)$, respiratory rate $(54.25 \pm 2.75)$ and pulse rate $(154.05 \pm 2.66)$ compared to clinically healthy calves body temperature $(38.94 \pm 0.11)$, respiratory rate $(29.1 \pm 1.15)$ and pulse rate $(93.3 \pm 1.71)$.

\subsection{Blood gas analysis}

The BRD affected calves showed significant $(\mathrm{P}<0.05)$ decrease in $\mathrm{pH}, \mathrm{PO}_{2}$ and $\mathrm{SO}_{2}$, and increase in $\mathrm{PCO} 2, \mathrm{HCO}_{3}$, and $\mathrm{tCO}_{2}$, when compared to healthy control calves (Table $1)$.

3.3. Acute phase proteins and proinflammatory cytokines BRD affected calves showed a significant $(\mathrm{p}<0.05)$ increase in $\mathrm{Hp}, \mathrm{SAA}, \mathrm{Fb}$ and IL-6 levels when compared to healthy calves (Table 2).

\subsection{Serum minerals and electrolytes}

BRD affected calves showed a significant $(\mathrm{P}<0.05)$ decrease in $\mathrm{Ca}, \mathrm{P}, \mathrm{Mg}, \mathrm{Na}$ and $\mathrm{Cl}$ when compared to healthy calves. On other hand, diseased calves exhibted a significant $(\mathrm{P}<$ 0.05 ) increase in $\mathrm{K}$ level when compared to healthy calves (Table 3)

3.4. Electrocardiographic findings

In healthy control calves, heart rhythm was normal in all calves (Fig. 1). While, in BRD affected calves heart rhythm 
showed some arrhythmias such as sinus tachycardia, sinus arrhythmia, and atrial fibrillation (Fig. 2-4). In comparison to control calves, the BRD calves showed significant $(\mathrm{P}<$ 0.05 ) increase in QRS amplitude, and $\mathrm{T}$ wave duration and amplitude. Also, there was significant $(\mathrm{P}<0.05)$ decrease in $\mathrm{P}$ wave duration and amplitude, $\mathrm{QRS}$ duration, $\mathrm{P}-\mathrm{R}$ interval and Q-t interval when com control group (Table 4).

Tables 1 Blood gas analysis of apparently healthy calves and BRD affected calves

\begin{tabular}{lcc}
\hline Parameters & Control $(\mathrm{n}=10)$ & BRD affected calves $(\mathrm{n}=20)$ \\
\hline $\mathrm{pH}$ & $7.43 \pm 0.006^{\mathrm{a}}$ & $7.33 \pm 0.012^{\mathrm{b}}$ \\
$\mathrm{HCO}(\mathrm{mmol} / \mathrm{L})$ & $25.71 \pm 0.72^{\mathrm{a}}$ & $28.81 \pm 0.46^{\mathrm{b}}$ \\
$\mathrm{PCO} 2(\mathrm{mmHg})$ & $40.09 \pm 0.98^{\mathrm{a}}$ & $56.11 \pm 1.07^{\mathrm{b}}$ \\
$\mathrm{PO}_{2}(\mathrm{mmHg})$ & $33.51 \pm 1.61^{\mathrm{a}}$ & $25.76 \pm 0.62^{\mathrm{b}}$ \\
$\mathrm{tCO}_{2}(\mathrm{mmol} / \mathrm{L})$ & $26.91 \pm 0.68^{\mathrm{a}}$ & $30.49 \pm 0.55^{\mathrm{b}}$ \\
$\mathrm{SO}_{2}(\%)$ & $64.60 \pm 3.04^{\mathrm{a}}$ & $47.23 \pm 1.56^{\mathrm{b}}$
\end{tabular}

Data represented as Mean \pm SE. Superscript letters indicated significance difference between groups on $\mathrm{P}<0.05$

Table 2 Serum acute phase proteins and pro-inflammatory cytokines of apparently healthy and BRD affected calves

\begin{tabular}{lcc}
\hline Parameters & Control $(\mathrm{n}=10$ & BRD affected calves $(\mathrm{n}=20)$ \\
\hline SAA (mg/l) & $20.72 \pm 2.06^{\mathrm{a}}$ & $123.23 \pm 5.18^{\mathrm{b}}$ \\
$\mathrm{Hp}(\mathrm{mg} / \mathrm{dl})$ & $1.177 \pm 0.1^{\mathrm{a}}$ & $6.69 \pm 0.26^{\mathrm{b}}$ \\
$\mathrm{Fb}(\mathrm{g} / \mathrm{l})$ & $3.79 \pm 0.24^{\mathrm{a}}$ & $9.79 \pm 0.70^{\mathrm{b}}$ \\
$\mathrm{IL}-6(\mathrm{ng} / \mathrm{l})$ & $94.54 \pm 4.16^{\mathrm{a}}$ & $276.42 \pm 5.08^{\mathrm{b}}$
\end{tabular}

Data represented as Mean \pm SE. Superscript letters indicated significance difference between groups on $\mathrm{P}<0.05$.

Table 3 Serum mineral and electrolyte level of apparently healthy and BRD affected calves

\begin{tabular}{lcc}
\hline Parameters & Control $(\mathrm{n}=10)$ & BRD calves $(\mathrm{n}=20)$ \\
\hline $\mathrm{Ca}(\mathrm{mg} / \mathrm{dl})$ & $9.52 \pm 0.23^{\mathrm{a}}$ & $6.12 \pm 0.32^{\mathrm{b}}$ \\
$\mathrm{P}(\mathrm{mg} / \mathrm{dl})$ & $6.10 \pm 0.42^{\mathrm{a}}$ & $4.57 \pm 0.23^{\mathrm{b}}$ \\
$\mathrm{Mg}(\mathrm{mmol} / \mathrm{l})$ & $0.934 \pm 0.023^{\mathrm{a}}$ & $0.778 \pm 0.019^{\mathrm{b}}$ \\
$\mathrm{Na}(\mathrm{mmol} / \mathrm{l})$ & $140.68 \pm 1.75^{\mathrm{a}}$ & $130.72 \pm 1.01^{\mathrm{b}}$ \\
$\mathrm{K}(\mathrm{mmol} / \mathrm{l})$ & $4.32 \pm 0.11^{\mathrm{a}}$ & $6.26 \pm 0.18^{\mathrm{b}}$ \\
$\mathrm{Cl}(\mathrm{mmol} / \mathrm{l})$ & $106.84 \pm 1.37^{\mathrm{a}}$ & $88.13 \pm 1.23^{\mathrm{b}}$
\end{tabular}

Data represented as Mean \pm SE. Superscript letters indicated significance difference
between groups on $\mathrm{P}<0.05$.

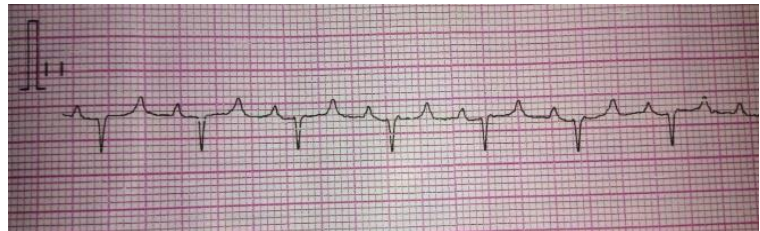

Figure 1 ECG trace showing normal ECG trace in healthy control calves using base-pex lead system. The heart rate was $89 \mathrm{beat} /$ minute. Trace was recorded at a paper speed of 25 lead system. The heart rate was 89 bee $\mathrm{mm} / \mathrm{sec}$ and calibration of $10 \mathrm{~mm} / \mathrm{mV}$

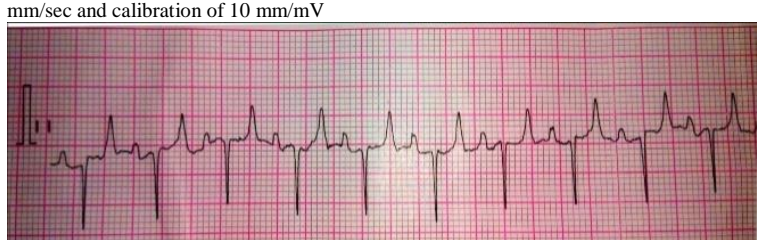

Figure 2 ECG trace of BRD affected calves using base-pex lead system showed Sinus tachycardia; Sinus arrhythmia; increase T wave amplitude, QRS amplitude is increased $\mathrm{QRS}$ duration is decreased. The heart rate was $126 \mathrm{beat} / \mathrm{minute}$. Trace was recorded at a paper speed of $25 \mathrm{~mm} / \mathrm{sec}$ and calibration of $10 \mathrm{~mm} / \mathrm{mV}(1 \mathrm{~cm}=1 \mathrm{mV})$

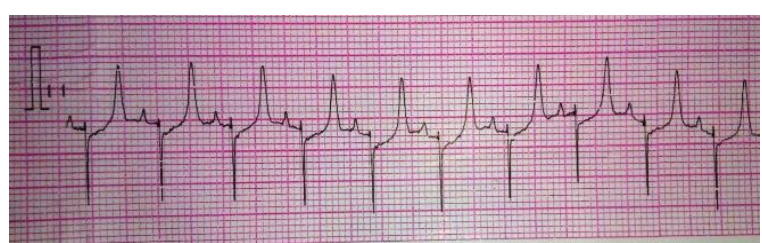

Figure 3 ECG trace in BRD affected calves showed Sinus tachycardia, peaked T wave amplitude. QRS amplitude was increased and QRS duration was decreased. The heart rate was 135 beat/minute. Trace is recorded at a paper speed of $25 \mathrm{~mm} / \mathrm{sec}$ and calibration of was $135 \mathrm{me}$

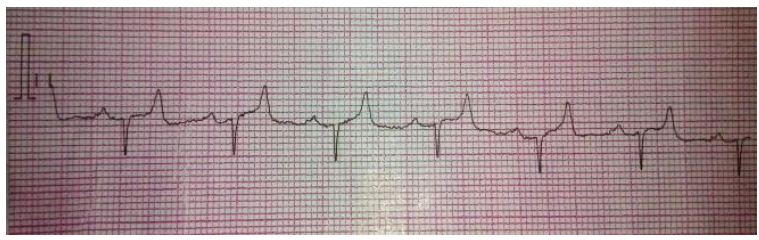

Figure 4 ECG trace of BRD affected calves using base-pex lead system showed Sinu arrhythmia (variable RR interval); atrial fibrillation (absence of $\mathrm{P}$ wave, presence of daughter waves and variable RR interval) longer T wave duration and amplitude. The hear rate was 82 beat per minute. Trace was recorded at a paper speed of $25 \mathrm{~mm} / \mathrm{sec}$ and calibration of $10 \mathrm{~mm} / \mathrm{mV}(1 \mathrm{~cm}=1 \mathrm{mV})$.

Table 4 ECG examination of apparently healthy calves and BRD affected calves

\begin{tabular}{lcc}
\hline Parameters & Control $(\mathrm{n}=10)$ & BRD affected calves $(\mathrm{n}=20)$ \\
\hline P wave Duration (Sec) & $0.0216 \pm 0.0007^{\mathrm{a}}$ & $0.0198 \pm 0.0013^{\mathrm{b}}$ \\
P wave Amplitude (mV) & $0.159 \pm 0.0417^{\mathrm{a}}$ & $0.125 \pm 0.0067^{\mathrm{b}}$ \\
QRS wave Duration (Sec) & $0.022 \pm 0.0007^{\mathrm{a}}$ & $0.012 \pm 0.0017^{\mathrm{b}}$ \\
QRS wave Amplitude (mV) & $0.52 \pm 0.011^{\mathrm{a}}$ & $0.98 \pm 0.086^{\mathrm{b}}$ \\
T wave Duration (Sec) & $0.0260 \pm 0.0116^{\mathrm{a}}$ & $0.0324 \pm 0.0145^{\mathrm{b}}$ \\
T wave Amplitude (mV) & $0.274 \pm 0.0073^{\mathrm{a}}$ & $0.64 \pm 0.0456^{\mathrm{b}}$ \\
P R Interval (Sec) & $0.0604 \pm 0.0007^{\mathrm{a}}$ & $0.0468 \pm 0.0021^{\mathrm{b}}$ \\
Q T Interval (Sec) & $0.1208 \pm 0.0014^{\mathrm{a}}$ & $0.0916 \pm 0.0038^{\mathrm{b}}$ \\
\hline
\end{tabular}

Data represented as Mean \pm SE. Superscript letters indicated significance difference between groups on $\mathrm{P}<0.05$.

\section{DISCUSSION}

The major clinical signs of BRD calves were shallow rapid respiration indicating hypoxia due to dyspnea that might be attributed to severe inflammation in the bronchioles and alveoli which interfere with gas exchange and respiration. In agreement with other studies, BRD affected calves showed a significant increase in $\mathrm{PCO}_{2}, \mathrm{tCO}_{2}$ and $\mathrm{HCO}_{3}$ and a significant decrease in $\mathrm{pH}, \mathrm{PO}_{2}$ and $\mathrm{SO}_{2}$ when compared to control group (Nagy et al., 2006; Fararh et al., 2017). The alteration of blood gas analysis may be attributed to the pathological actions of microorganisms on lung which lead to alteration in blood gas exchange and blood $\mathrm{pH}$ (Karademir et al., 1999). The increase in $\mathrm{HCO}_{3}$ level may be also attributed to response of kidney to the respiratory acidosis through renal retention of bicarbonate in exchange with chloride to maintain electrical neutrality (Kumar et al., 2018). The increase in $\mathrm{PCO}_{2}, \mathrm{HCO}_{3}$ and $\mathrm{tCO}_{2}$ and decrease in $\mathrm{PO}_{2}$ level may be attributed to a high respiratory frequency and aerobic metabolism to reduce the level of $\mathrm{CO}_{2}$ (Nagy et al., 2006; Smith, 2014). Decrease $\mathrm{PO}_{2}$ and $\mathrm{SO}_{2}$ besides the disturbance in gas exchanges might be attributed to the consumption of oxygen during metabolism that resulted from elevated WBCs count (Hussein and Aamer, 2013).

Serum APPs and proinflammatory cytokines of BRD calves revealed a significant increase of SAA, Hp, Fb and IL-6 which agreed with Fararh et al. (2017), Joshi et al. (2018) and Akgul et al. (2019). The proinflammatory cytokines are proteins that act as chemical messengers secreted by T-cells in response to the host immune responses (Ditchkoff et al., 2001). Colonization of respiratory pathogens causes release of proinflammatory cytokine and transcription of many cytokine genes particularly IL-6 (Ridpath, 2010). Development of BRD is also associated with complex signaling processes that play a crucial role in recognizing the 
microbial components by innate immune cells followed by phagocytosis of invading pathogens and production of IL-6 and other pro-inflammatory cytokines (Ackermann et al., 2010). Cytokines play an important role in elimination of the infection through modulation of other immune proteins (APPs) or stimulation of phagocytosis (Tothova et al., 2008). APPs are produced by both hepatocytes and peripheral tissues in response to inflammatory process (Ceciliani et al., 2012). Acute phase proteins have been proposed as sensitive and rapid indicators of inflammatory processes in ruminants (Gonzales et al., 2011). Increased $\mathrm{Hp}, \mathrm{SAA}, \mathrm{Fb}$ level might be a consequence of severe lung tissue injury as a result of the inflammation in BRD affected calves which highlight their role in host immunity (Orro et al., 2011). The rates of increment of $\mathrm{Hp}$ and SAA were different in BRD, while Hp increased immediately after infection, SAA took relatively longer time. These findings might be associated with different induction rates of APPs in liver (Joshi et al., 2018). In our study, SAA and Hp increased in all BRD affected calves with relatively similar level, which indicated that both SAA and $\mathrm{Hp}$ are highly sensitive to occurrences of BRD in calves. Fibrinogen was also highly increased in calves with BRD (Akgul et al., 2019). From this study, SAA had the highest increased value followed by, $\mathrm{Hp}$ and fibrinogen. These findings suggest that $\mathrm{Hp}$ and SAA were the best markers for detection of naturally occurring respiratory disease in cattle (Abdelbaset et al., 2014).

The serum minerals and electrolyte levels of BRD calves revealed significant $(P<0.05)$ decrease of $\mathrm{Ca}, \mathrm{P}, \mathrm{Mg}, \mathrm{Na}$ and $\mathrm{Cl}$ when compared to control group. On other hand, BRD affected calves showed significant $(P<0.05)$ increase in $\mathrm{K}$ when compared to control calves. This result is in agreement with Ismael et al. (2017). Inappetence or anorexia as a result of respiratory disease might explain the lower plasma concentrations of measured minerals (Kumar et al., 2018). The decreased in serum $\mathrm{Ca}$ might be resulted from the anorexia, decreased intestinal absorption or increased renal excretion and the significant decrease in serum $\mathrm{P}$ concentrations seemed to be secondary to reduced phosphorus absorption from the gut and tissues (Saleh and Allam, 2014). Higher K concentrations in serum could be seen as well in BRD cases because $\mathrm{H}+$ ions accumulated in the extracellular fluid is exchanging with $\mathrm{K}$ present in the intracellular fluid (Kaneko et al., 2008). Reduction of serum $\mathrm{Cl}$ and increased $\mathrm{K}$ level might be also attributed to hyperpyrexia in acute respiratory disease and metastatic infection of kidneys (Constable et al., 2017)

ECG findings of BRD affected calves in this study showed a significant decrease in P-wave amplitude and duration (reduced atrial contractility or depolarization), which agreed with Devi et al. ( 2015). This could be attributed to atrial fibrillation or supraventricular pacemaker fibrillation as a result of myocardial hypoxia (Gelberg et al., 1991; Reef and McGuirk, 1996). This also could be resulted from the alteration in hemodynamic/acid-base balance or hypoxic changes as a result of respiratory distress (Smith, 2014; Devi et al. 2015). Reduced atrium contractility (depolarization) might be resulted from the hypocalcemia and the significant decrease in QRS-wave duration resulted from increased heart rate with interference with pulmonary circulation and agreed with Gelberg et al. (1991), Reef and McGuirk (1996) and Devi et al. (2015). On the other hand, the significant increase in T-wave amplitude, with a significant decrease in
P-R interval and Q-T interval might be attributed to disturbance in ventricular relaxation or ventricular hypertrophy (Smith, 2014; Devi et al., 2015). Moreover, the electrolyte imbalance (hyperkalemia) resulted in increase in the peaking of $\mathrm{T}$ wave (Johri et al., 2009).

\section{CONCULOSION}

In conclusion, our study showed that the BRD was associated with changes in pulmonary function, APPs, proinflammatory cytokines, electrolyte balance and electrocardiographic traces. Pulmonary function test, APPs and proinflammatory cytokines are valuable tools in early diagnosis of BRD so they should be included in at the time of initial diagnosis of BRD.

\section{REFERENCES}

1. Abdallah, A., Hewson, J., Francoz, D., Selim, H., Buczinski, S., 2016. Systematic review of the diagnostic accuracy of haptoglobin, serum amyloid $\mathrm{A}$, and fibrinogen versus clinical reference standards for the diagnosis of bovine respiratory disease. Journal of veterinary internal medicine, 30 (4), 13561368.

2. Abdelbaset, A. E., Ellah, M. A., ElGhaffar, S. K. A., Sadiek, A. H., 2013. Evaluation of Haptoglobin and Fibrinogen levels in Some Pathological Lung affections in Buffaloes. XX International Congress of Mediterranean Federation of Health and Production of Ruminants. Assiut University, Egypt. Pp. 19-22.

3. Ackermann, M. R., Derscheid, R., Roth, J. A., 2010. Innate immunology of bovine respiratory disease. Veterinary Clinics of North America: Food Animal Practice, 26(2), 215-228.

4. Akgul, O., Kozat, S., Ozkan, C., Kaya, A., Akgul, Y., 2019. Evaluation of acute phase protein levels and some cytokine levels in pneumonic calves. Medycyna Weterynaryjna, 75(03).Perino, L.J. and Apley, M.D., 1998. Clinical trial design in feedlots. Vet. Clinics: Food Anim. Pract. 14: 343 365 .

5. Alsemgeest, S. P. M., Lambooy, I. E., Wierenga, H. K., Dieleman, S. J., Meerkerk, B., Van Ederen, A. M., Niewold, T. A., 1995. Influence of physical stress on the plasma concentration of serum amyloid-a (SAA) and haptoglobin (HP) in calves. Veterinary Quarterly, 17(1), 9-12.

6. Arslan, H. H., Ozcan, U., 2018. Current Approach to Bovine Respiratory Disease. Journal of Dairy \& Veterinary Sciences Review Article, 5 (2).

7. Bailey, R. A., 2008. Design of comparative experiments (Vol. 25). Cambridge University Press. Pp.128-116.

8. Becker, U., Bartl, K., Wahlefeld, A. W., 1984. A functiona photometric assay for plasma fibrinogen. Thrombosis research, 35(5), 475-484.

9. Ceciliani, F., Ceron, J. J., Eckersall, P. D., Sauerwein, H., 2012. Acute phase proteins in ruminants. Journal of proteomics, 75(14), 4207-4231.

10. Cheesbrough, M., 1991. Medical laboratory Manual for Tropical countries 2nd edition. Topical health Technology and Butterworth Scientific limited. (1), 494-529.

11. Constable, P. D., Hinchcliff, K. W., Done, S. H., Grünberg, W., 2017. Veterinary Medicine-e-book: a textbook of the diseases of cattle, horses, sheep, pigs and goats. Elsevier Health Sciences. Elven Edition, Veterinary medicine, 11, pp: 915-930.

12. Devi, S., Varshney, J. P., Undhirwade, S. C., Jadhav, K. M., 2015. A clinical study on electrocardiographic changes in goats suffering from pneumonia. Indian Journal of Small Ruminants, 21(1), 138-140.

13. Devlin, T.M., 1997. Textbook of Biochemistry with Clinical Correlations.Wiles-Liss, Inc., USA. Pp.1129-1136. 
14. Ditchkof, S. S., Sams, M. G., Lochmiller, R. L., Leslie, J. R., 2001. Utility of necrosis factor-a and interleukin-6 as predictors of neonatal mortality in white-tailed deer. Journal of Mammalogy, 82, 239-245.

15. Fararh, K. M., Abd EL-Hamied, S.S., Farid, A.S. ElSharkawy, R.B., 2017. Clinicopathological changes in calves with respiratory diseases after treatment with essential volatile oil and other drugs. Benha Veterinary Medical Journal, 33(2), 237-247.

16. Gelberg, H. B., Smetzer, D. L., Foreman, J. H., 1991. Pulmonary hypertension as a cause of atrial fibrillation in young horses: four cases (1980-1989). Journal of the American Veterinary Medical Association, 198(4), 679-682.

17. Ghanem, M. M., 1997. Evaluation of electrocardiography as an aid for diagnosis of some equine affections. Master thesis submitted to faculty of Vet. Medicine, Zagazig University, Benha Branch.

18. González, F. H., Hernández, F., Madrid, J., Martínez-Subiela, S., Tvarijonaviciute, A., Cerón, J. J., Tecles, F., 2011. Acute phase proteins in experimentally induced pregnancy toxemia in goats. Journal of Veterinary Diagnostic Investigation, 23(1), 57-62.

19. Heller, M. C. and Johns, J. L., 2015. Acute phase proteins in healthy goats: establishment of reference intervals. Journal of Veterinary Diagnostic Investigation, 27(2), 177-181.

20. Hussein, H. A., Aamer, A. A., 2013. Influence of different storage times and temperatures on blood gas and acid-base balance in ovine venous blood. Open veterinary journal, 3(1), 1-7.

21. Idoate, I., Vander Ley, B., Schultz, L., Heller, M., 2015. Acute phase proteins in naturally occurring respiratory disease of feedlot cattle. Veterinary immunology and immunopathology, 163(3), 221-226.

22. Ismael, M., El-Sayed, M. S., Metwally, A. M., Ibrahim, Z. K., El-Saman, A. E. R. M., 2017. Clinical and Haematobiochemical Evaluation of Pneumonia in Calves with Special Reference to Oxidant/Antioxidant Indices. Alexandria Journal for Veterinary Sciences, 54(2), 40-44.

23. Johri, A. M., Baranchuk, A., Simpson, C. S., Abdollah, H., Redfearn, D. P., 2009. ECG Manifestations of Multiple Electrolyte Imbalance: Peaked T Wave to P Wave ("Tee-Pee Sign"). Annals of Noninvasive Electrocardiology, 14(2), 211214.

24. Joshi, V., Gupta, V. K., Bhanuprakash, A. G., Mandal, R. S. K., Dimri, U., Ajith, Y., 2018. Haptoglobin and serum amyloid A as putative biomarker candidates of naturally occurring bovine respiratory disease in dairy calves. Microbial pathogenesis, 116, 33-37.

25. Kabu, M., Elitok, B., Kucukkurt, I., 2016a. Detection of serum amyloid-A concentration in the calf clinically diagnosed with pneumonia, enteritis and pneumoenteritis. Ciência Rural, 46(2), 293-299.
26. Kaneko, J. J., Harvey, J. W., Bruss, M. L., 2008. Clinical biochemistry of domestic animals.6th Ed. Academic Press, London. Pp.117-138.

27. Karademir, B., Saatci, M., Celebi, F., Erdoğan, H. M., Aksoy, A. R., 1999. Venous blood gases values of cattle kept in closed barn conditions in Caucasian. Kafkas University Faculty of Veterinary Medicine Journal, 5, 155-159.

28. Kumar, P., Jain, V., Kumar, T., Kumar, V., Rana, Y., 2018 Clinical and Haematobiochemical Studies on Respiratory Disease in Buffaloes. International Journal of Livestock Research, 8(8), 178-184.

29. Loneragan, G. H., Dargatz, D. A., Morley, P. S., Smith, M. A. 2001. Trends in mortality ratios among cattle in US feedlots. Journal of the American Veterinary Medical Association, 219(8), 1122-1127.

30. McGuirk, S.M., 2008. Disease management of dairy calves and heifers. The Veterinary clinics of North America. Food animal practice 24, 139-153.

31. Nagy, O., Seidel, H., Paulikova, I., Mudron, P., Kovac, G., 2006. Use of blood gases and lactic acid analyses in diagnosis and prognosis of respiratory diseases in calves. BulletinVeterinary Institute in Pulawy, 50(2), 149.

32. Orro, T., Pohjanvirta, T., Rikula, U., Huovilainen, A., Alasuutari, S., Sihvonen, L., Pelkonen, S., Soveri, T., 2011. Acute phase protein changes in calves during an outbreak of respiratory disease caused by bovine respiratory syncytial virus. Comparative immunology, microbiology and infectious diseases, 34(1), 23-29.

33. Radostits, O. M., Mayhew, I. G., Houston, D. M. 2000. Veterinary clinical examination and diagnosis. WB Saunders. Pp:299-349

34. Reef, V.B. and McGuirk, S.M., 1996: Congenital cardiovascular disease. In Smith BP, editor: Large animal internal medicine, second Ed. St Louis, Mosby.

35. Ridpath, J. F., 2010. Bovine viral diarrhea virus: globa status. Veterinary Clinics: Food Animal Practice, 26(1), 105121

36. Saleh, N. S. and Allam, T. S. 2014. Pneumonia in sheep bacteriological and clinicopathological studies. American Journal of Research Communication, 2(11), 70-88.

37. Smith, B. P., 2014. Large animal internal medicine. $5^{\text {th }}$ ed-EBook. Elsevier Health Sciences. Pp: 585-658.

38. Thompson, P. N., Stone, A., Schultheiss, W. A., 2006. Use of treatment records and lung lesion scoring to estimate the effect of respiratory disease on growth during early and late finishing periods in South African feedlot cattle. Journal of animal science, 84(2), 488-498.

39. Tothova, C. S., Nagy, O., Seidel, H., Konvičná, J., Farkašová, Z., Kováč, G., 2008. Acute phase proteins and variables of protein metabolism in dairy cows during the pre-and postpartal period. Acta Veterinaria Brno, 77(1), 51-57.

40. Zeineldin, M., Lowe, J., Aldridge, B., 2019. Contribution of the mucosal microbiota to bovine respiratory health. Trends in microbiology, 27(9), 753-770. 